\title{
PENINGKATAN KEMAMPUAN BAHASA ANAK MELALUI METODE BERCERITA DENGAN MEDIA DIORAMA
}

\author{
Denok Dwi Anggraini \\ IAIN Madura \\ Email: denok@iainmadura.ac.id
}

\begin{abstract}
The purpose of this research was to determine the process of implementation of learning activities using storytelling methods with dioramas media in improving the language skills of children in group $B$ and to know the extent of the results of improving children's language skills through storytelling methods with dioramas in group $B$. The method used in this research is an action research which refers to the model of a Classroom Action Research Kemmis and Mc. Taggart consist of four phase: planning, action, observation and reflection. This research consist of two cycles, each cycle consist of 6 times in actions. Analysis of the data used quantitative and qualitative approaches. Analysis of quantitative data used descriptive statistics that compare the results obtained from the first cycle and the second cycle. While the analysis of qualitative data used analyzing data from the field notes and interviews during the research by steps of data reduction, data display and data verification. The results showed an improvement in language skills through storytelling methods with dioramas, as evidenced by the average pre-action language proficiency score of children by 39\%. Then increased in cycle I by $20 \%$ to $59 \%$. Furthermore, from cycle I to cycle II children's language skills increased by $30 \%$ from $59 \%$ to $89 \%$. So that the total improvement of children's language skills ranging from pre-action, cycle I to cycle II $39 \%$ which is $59 \%$ to $89 \%$.
\end{abstract}

Key words: language skills; storytelling; dioramas media

Asbtrak: Tujuan dari penelitian ini adalah untuk mengetahui proses kegiatan pembelajaran menggunakan metode bercerita dengan media diorama dalam meningkatkan kemampuan bahasa anak kelompok $B$ dan mengetahui sejauh mana hasil peningkatan kemampuan bahasa anak melalui metode bercerita dengan media diorama di kelompok B. Metode yang digunakan dalam penelitian ini adalah Penelitian Tindakan yang mengacu pada model Penelitian Tindakan Kelas dari Kemmis dan Mc. Taggart yang meliputi empat tahap yaitu perencanaan, tindakan, pengamatan, refleksi. Penelitian ini terdiri dari dua siklus, masing-masing siklus terdiri dari 6 kali pertemuan. Analisis data menggunakan data kuantitatif dan kualitatif. Analisis data kuantitatif dengan statistic deskriptif yaitu membandingkan hasil yang diperoleh dari siklus pertama dan siklus kedua. Sedangkan analisis data kualitatif dengan cara menganalisis data dari hasil catatan lapangan dan wawancara selama penelitian dengan langkah-langkah reduksi data, display data dan verifikasi data. Hasil penelitian menunjukkan adanya peningkatan kemampuan bahasa melalui metode bercerita dengan media diorama, dapat dibuktikan rata-rata skor kemampuan bahasa pra tindakan anak sebesar $39 \%$. Kemudian mengalami peningkatan pada siklus I sebesar $20 \%$ sehingga menjadi $59 \%$. Selanjutnya dari siklus I ke siklus II kemampuan bahasa anak mengalami peningkatan sebesar $30 \%$ dari 59\% menjadi $89 \%$. Sehingga total peningkatan kemampuan bahasa anak mulai dari pra tindakan, siklus I sampai siklus II $39 \%$ yaitu $59 \%$ menjadi $89 \%$.

Kata kunci: kemampuan bahasa; bercerita; media diorama 
Denok Dwi A, Peningkatan Kemampuan Bahasa Anak Melalui Metode Bercerita Dengan Media Diorama

\section{PENDAHULUAN}

Taman Kanak-Kanak (TK) merupakan salah satu lembaga tempat pendidikan anak usia dini yang berada pada jalur formal, di mana pada usia ini merupakan masa keemasan (golden age) khususnya usia 5-6 tahun, dengan adanya TK bertujuan membantu mengembangkan potensi yang dimiliki oleh anak antara lain nilai-nilai agama dan moral, sosial, emosional, kognitif, bahasa, fisik motorik, dan juga kemandirian. Oleh karena itu, stimulasi yang tepat sangat menentukan proses perkembangan anak lebih lanjut, misalnya dengan belajar melalui bermain. Apabila anak mendapatkan stimulus yang baik, maka seluruh aspek perkembangan anak akan berkembang secara optimal. Oleh karena itu pendidikan anak usia dini harus dapat merangsang seluruh aspek perkembangan anak baik perkembangan perilaku, bahasa, kognitif, sosial emosional, kemandirian maupun fisik motorik. ${ }^{1}$

Perkembangan bahasa merupakan salah satu aspek perkembangan yang penting. Karena bahasa merupakan media sarana komunikasi dengan seseorang dan juga bermanfaat bagi kehidupan. Dengan demikian perkembangan bahasa harus diberikan anak sejak usia dini. Anak usia dini harus dilatih untuk berani mengungkapkan apa yang ia rasakan dan dipikirkan. Sehingga pada nantinya anak tidak akan menjadi pemalu, mudah mengungkapkan pendapat di depan banyak orang dan mudah berinteraksi. Oleh karena itu, pengembangan bahasa harus dioptimalkan dan dikembangkan sejak anak usia dini.

Permasalahan yang terjadi di TK pada anak kelompok B yang seluruhnya berjumlah 28 anak, dari jumlah tersebut anak yang mampu mengembangkan kemampuan bahasanya hanya 40\% yaitu sekitar 12 anak. Sebagian besar anak masih kesulitan dalam mengungkapkan bahasa. Namun pada kenyataannya yang terjadi pada saat ini tidak

1Sumiyati. Konsep Dasar Pendidikan Anak Usia Dini dalam Islam. Indie Book Corner. 2014:12. 
semua guru di TK yang ada, mampu menyampaikan metode bercerita dengan baik, metode cerita di sajikan langsung dari guru tanpa menggunakan alat peraga apapun, sehingga kurang menarik perhatian anak didik dalam memahami isi cerita yang ada.

Anak didik seringkali kurang mendapat perhatian dari guru dalam mengungkapkan sebuah perasaan atau idenya, sehingga kemampuan bahasa yang di miliki oleh anak tidak berkembang secara optimal. Selain itu tidak jarang guru lebih fokus pada kegiatan keterampilan membaca dan menulis serta berhitung, dengan alasan kegiatan keterampilan membaca dan menulis serta berhitung adalah salah satu tuntutan untuk jenjang pendidikan selanjutnya, yaitu ketika anak usia dini memasuki Sekolah Dasar (SD). Sehingga anak usia dini kurang mampu mengungkapkan perasaan atau ide ketika menjawab pertanyaan dari guru dan tidak paham dengan informasi yang telah di sampaikan oleh guru. Oleh karena itu metode bercerita dengan menggunakan media diorama sangat dibutuhkan dalam meningkatkan kemampuan bahasa anak, agar dikemudian hari anak tidak mengalami kegagalan dalam berbahasa.

Penerapan teknik bercerita inidiharapkan dapat mengatasi perbedaan minat belajar anak. Penyajian teknik bercerita yang baik dapat menumbuhkan imajinasi dan mendorong kreativitas anak dalam mengangkat pesan atau informasi yang disampaikan. Selain itu, melalui cerita pada saat anak mendengarkan dan mengikuti jalan cerita, pada saat itu juga emosi, fantasi, maupun imajinasi anak-anak menjadi aktif. Selain itu, dunia anak-anak identik dengan dunia tanpa batas, dalam artian apa yang mereka dengar, lihat dan rasakan akan mempengaruhi daya pikir mereka dan itu akan berbekas di dalam pikiran mereka dalam waktu yang relatif lama. Sehingga dapat disimpulkan bahwa pembelajaran melalui metode bercerita merupakan sarana yang efektif untuk mendidik dan mengajari anak tanpa adanya kesan menggurui. ${ }^{2}$ Berdasarkan uraian

${ }^{2}$ R, Amalia, E. Meningkatkan Perkembangan Bahasa Anak Usia Dini Dengan Metode Bercerita. https://doi.org/10.31219/osf.io/kr5fw. 2019. 
Denok Dwi A, Peningkatan Kemampuan Bahasa Anak Melalui Metode Bercerita Dengan Media Diorama

di atas, permasalahan yang terjadi tidak terlepas dari kurangnya wawasan guru dalam memilih metode dan media pembelajaran yang tepat. Oleh karena itu peneliti ingin melakukan penelitian tindakan kelas pada anak kelompok $\mathrm{B}$ dengan harapan dapat melakukan perbaikan dan dapat meningkatkan perkembangan bahasa anak, melalui metode bercerita dengan menggunakan media diorama, dengan metode tersebut di harapkan kegiatan pembelajaran bermakna dan menyenangkan serta tidak membosankan lagi bagi anak, dengan metode dan penggunaan media tersebut di harapkan kemampuan bahasa anak tercapai dengan baik.

\section{METODE}

Metode penelitian yang digunakan adalah penelitian tindakan (action research). Penelitian tindakan menggunakan desain model Kemmis \& Mc Taggart ini meliputi empat tahap yaitu (1) perencanaan (planning), (2) tindakan (action), (3) pengamatan (observation), (4) refleksi (reflection). Pada model Kemmis \& Taggart tindakan (acting) dan observasi (observing) dijadikan sebagai satu kesatuan karena mereka menganggap bahwa kedua komponen tersebut merupakan dua kegiatan yang tidak bisa dipisahkan. ${ }^{3}$

Keberhasilan secara klasikal mengikuti standar George E. Mills dalam penelitiannya yaitu menetapkan persentase $81 \% .{ }^{4}$ Teknik pengumpulan data yang digunakan dalam penelitian ini adalah dokumentasi, wawancara, dan observasi. Dokumentasi dalam penelitian ini yaitu mengumpulkan informasi tentang laporan hasil perkembangan bahasa anak, foto dan video kegiatan pembelajaran menggunakan metode bercerita dengan media diorama. Wawancara dilakukan kepada

${ }^{3}$ Arikunto, Suharsimi. Prosedur Penelitian Suatu Pendekatan Praktik. PT. Rineka Cipta. 2013:132.

4Stephen Kemmisdan Robin Mc Taggart. The Action Research Planner. Deakin University. 1990:162. 
kepala sekolah yang sekaligus guru kelompok B, orang tua, dan anak untuk memperoleh informasi secara mendalam tentang kemampuan bahasa anak dari kegiatan pembelajaran menggunakan metode bercerita dengan media diorama. Observasi dilakukan dengan menggunakan catatan lapangan, untuk mencatat berbagai kegiatan yang terdiri dari catatan tertulis tentang apa yang dilihat, didengar, dialami dan dipikirkan oleh peneliti dalam rangka mengumpulkan data.

Kisi-kisi instrument dikembangkan melalui definisi konseptual dan operasional yang menjelaskan bahwa kemampuan bahasa adalah skor yang diperoleh dari pengamatan terhadap anak tentang aspek mendengarkan, berbicara, membaca, menulis dengan menggunakan lembar observasi. Cara pemberian skor adalah melihat kemampuan bahasa anak dengan tingkatan: berhasil dan tidak.

Pengolahan data dalam penelitian ini menggunakan dua jenis data, sesuai dengan tuntutan penelitian tindakan, yaitu data kualitatif dan kuantitatif. Analisis data penelitian menggunakan analisis data kuantitatif dengan statistic deskriptif. Analisa kuantitatif digunakan dengan cara membandingkan hasil yang diperoleh dari siklus pertama dan siklus kedua. Analisis data kualitatif dengan cara menganalisis data dari hasil catatan lapangan dan wawancara selama penelitian dengan langkahlangkah reduksi data, display data dan verifikasi data yang dilakukan dalam suatu proses. ${ }^{5}$

\section{KERANGKA TEORI}

Bahasa merupakan alat untuk berinteraksi antar individu, yang memegang peranan penting sejak individu masih berada pada usia dini. Bahasa dapat didefinisikan sebagai kode yang diterima secara sosial atau sistem konvensional untuk menyampaikan konsep melalui penggunaan simbol-simbol yang dikehendaki dan kombinasi simbol-simbol yang diatur

${ }^{5}$ Sudjana. Metode Statistika. Bandung: Tarsito. 2005:67. 
Denok Dwi A, Peningkatan Kemampuan Bahasa Anak Melalui Metode Bercerita Dengan Media Diorama

oleh ketentuan. ${ }^{6}$ Bahasa adalah suatu alat komunikasi yang digunakan melalui suatu sistem suara, kata, pola yang digunakan manusia untuk menyampaikan pertukaran pikiran dan perasaan. ${ }^{7}$ Sedangkan menurut Suhartono, bahasa merupakan rangkaian bunyi yang melambangkan pikiran, perasaan, serta sikap manusia. ${ }^{8}$ Selain itu Bromley mendefinisikan bahasa sebagai sistem simbol yang teratur untuk mentransfer berbagai ide maupun informasi yang terdiri dari simbol-simbol visual maupun verbal. ${ }^{9}$ Berdasarkan pendapat di atas dapat ditegaskan bahwa bahasa adalah simbol-simbol maupun rangkaian bunyi untuk menyampaikan konsep, mentransfer ide, informasi dan mampu membawakan pikiran dan perasaan yang bersifat konkrit maupun abstrak.

Sebagaimana kita ketahui bahwa kemampuan berbahasa pada anak usia dini meliputi 3 aspek, yaitu (1) aspek menerima bahasa: mengerti beberapa perintah secara bersamaan, mengulang kalimat yang lebih kompleks dalam judul cerita, memahami aturan yang berlaku di rumah maupun di sekolah; (2) aspek mengungkap bahasa: menjawab pertanyaan yang lebih kompleks dalam judul cerita, menyebutkan kelompok gambar yang memiliki bunyi yang sama, berkomunikasi secara lisan; mampu menjawab pertanyaan yang diajukan, memiliki perbendaharaan kata serta mengenal simbol- simbol untuk persiapan membaca, menulis, dan berhitung; mampu menyebutkan nama dan jumlah tokoh dalam cerita menyusun kalimat sederhana dalam struktur lengkap (pokok kalimat-predikat-keterangan); memiliki lebih banyak kata untuk mengekspresikan ide pada orang lain; melanjutkan sebagian cerita/dongeng yang telah diperdengarkan; (3) aspek keaksaraan:

${ }^{6}$ Conny R, Semiawan. Belajar dan Pembelajaran Prasekolah dan Sekolah Dasar. PT. Indeks. 2008:111.

${ }^{7}$ EnengHemah, dkk. Meningkatkan Kemampuan Bahasa Anak Melalui Metode Bercerita Pada Anak Usia 5-6 Tahun. Jurnal Penelitian Dan Pengembangan Pendidikan Anak Usia Dini, 5(1), 1. https://doi.org/10.30870/jpppaud.v5i1.4675. 2018.

${ }^{8}$ Suharto. Pengembangan Keterampilan Bicara Anak Usia Dini. Departemen Pendidikan Nasional. 2005:8.

${ }^{9}$ Nurbiana, Dhieni. Metode Pengembangan Bahasa. Universitas Terbuka. 2005:1.8. 
menyebutkan simbol-simbol huruf yang dikenal; mengenal suara huruf awal dari nama benda-benda yang ada disekitarnya; menyebutkan kelompok gambar yang memiliki bunyi huruf awal yang sama; memahami hubungan antara bunyi dan bentuk- bentuk; membaca nama sendiri; menuliskan nama sendiri. ${ }^{10}$

Oleh karena itu ketiga aspek tersebut sangat berpengaruh terhadap perkembangan kemampuan bahasa anak, kemampuan bahasa anak dapat dinyatakan berkembang secara optimal jika anak dapat menerima dan mengungkapkan bahasa dengan baik, serta dapat mengenal, memahami keaksaraan denganbaik. Metode yang tepat dalam meningkatkan kemampuan Bahasa anak salah satunya yaitu dengan menggunakan metode bercerita.

Bercerita adalah suatu kegiatan yang dilakukan seseorang secara lisan kepada orang lain dengan alat atau tanpa alat tentang apa yang harus disampaikan dalam bentuk pesan, informasi atau hanya sebuah dongeng yang untuk didengarkan dengan rasa menyenangkan, oleh karena itu orang yang menyajikan cerita tersebut menyampaikannya dengan menarik. ${ }^{11}$

Menurut Bachir, bercerita adalah menuturkan sesuatu yang mengisahkan tentang perbuatan atau sesuatu kejadian dan disampaikan secara lisan dengan tujuan membagikan pengalaman dan pengetahuan kepada orang lain. ${ }^{12}$ Berdasarkan pengertian tersebut maka cerita anak dapat didefinisikan "tuturan lisan, karya bentuk tulis atau pementasan tentang suatu kejadian, peristiwa, dan sebagainya yang terjadi di seputar

\footnotetext{
${ }^{10}$ Kementrian Pendidikan Nasional RI. (2014). Standar Nasional Pendidikan Anak Usia Dini No 137 Tahun 2014. Peraturan Menteri PendidikanDan Kebudayaan Republik Indonesia, 1-76.

${ }^{11}$ Nurbiana, Op.cit, h.6.3.

${ }^{12 S}$ Bachtiar, Bachir. Pengembangan Kegiatan Bercerita, Teknik dan Prosedurnya. Departemen Pendidikan dan Kebudayaan. 2005:10.
} 
Denok Dwi A, Peningkatan Kemampuan Bahasa Anak Melalui Metode Bercerita Dengan Media Diorama

dunia anak. ${ }^{13}$ Berdasarkan keberagaman pengertian metode bercerita di atas dapat disimpulkan sebagai berikut: "metode bercerita adalah cara bertutur kata dalam penyampaian cerita atau memberikan penjelasan kepada anak secara lisan", dalam upaya memperkenalkan ataupun memberikan keterangan hal baru pada anak.

Media diorama merupakan media tiga dimensi atau sering disebut media serba aneka. Rayandra Asyar mengungkapkan bahwa media tiga dimensi merupakan media yang tampilannya dapat diamati dari arah pandang mana saja dan mempunyai dimensi panjang, lebar, dan tebal. ${ }^{14}$ Kebanyakan media tiga dimensi merupakan objek sesungguhnya atau miniatur objek. Daryanto berpendapat bahwa media diorama merupakan salah satu media tanpa proyeksi yang disajikan secara visual tiga dimensional berwujud sebagai tiruan yang mewakili aslinya. Media diorama dapat digunakan dalam pembelajaran untuk mewakili benda asli yang sulit untuk disajikan di dalam kelas. ${ }^{15}$

Cecep Kustandi dan Bambang Sutjipta berpendapat bahwa diorama adalah gambaran kejadian baik yang mempunyai nilai sejarah atau tidak yang disajikan dalam bentuk mini atau kecil. ${ }^{16}$ Pendapat tersebut menjelaskan bahwa diorama memberikan informasi berupa peristiwa yang disajikan dalam bentuk tiruan lebih kecil dari aslinya.

Berdasarkan pernyataan beberapa ahli di atas tentang diorama, dapat disimpulkan bahwa diorama merupakan gabungan antara model dengan gambar perspektif dalam suatu penampilan utuh yang menggambarkan suasana sebenarnya. Dalam penelitian ini diorama berfungsi untuk memberikan gambaran visual dari suatu objek yang akan

\footnotetext{
${ }^{13}$ Tadkiroatun Musfiroh. Bercerita untuk Anak Usia Dini. Jakarta: Departemen Pendidikan Nasional. 2005:59

${ }^{14}$ Rayandra, Asyhar. Kreatif Mengembangkan Media Pembelajaran. Jakarta: Referensi. 2012:47.

${ }^{15}$ Daryanto. Media Pembelajaran. Gava Media. 2013:29.

${ }^{16}$ Cecep Kustandi \& Bambang Sutjipto. Media Pembelajaran. Jakarta: Ghalia Indonesia. 2013:50.
} 
dideskripsikan anak dalam bentuk yang lebih kecil, membawa ke dalam kelas suatu objek yang akan dideskripsikan oleh anak, dan sebagai pengganti objek yang sebenarnya yang tidak memungkinkan untuk dibawa ke dalam kelas. Dengan media diorama, anak mampu mengamat ilebih rinci tentang suatu objek yang akan dideskripsikan.

\section{TEMUAN DAN PEMBAHASAN}

Hasil penelitian menunjukkan bahwa kemampuan bahasa anak sudah mulai meningkat dari setiap pertemuannya dari tindakan prasiklus, siklus pertama sampai siklus kedua yang setiap siklusnya dilakukan selama 4 kali pertemuan. Hal ini dilakukan untuk memperoleh data yang stabil.

Penelitian prasiklus yang dilakukan sebelumnya diperoleh data kemampuan bahasa anak dengan kategori rendah, hal ini di karenakan sebagian besar anak masih banyak yang belum mampu menjawab pertanyaan maupun mengungkapkan kembali isi cerita dari guru. Asesmen awal pada penelitian prasiklus ini dilakukan untuk mengetahui kondisi awal kemampuan bahasa anak. Adapun hasil asessmen awal untuk kemampuan bahasa anak adalah:

Tabel1

Hasil Asesmen Awal Pra-Siklus I Kemampuan Bahasa Anak

\begin{tabular}{|c|c|c|c|c|c|c|}
\hline No. & Nama Anak & Observer I & Observer II & Skor & Persentase & Ket \\
\hline 1. & $\mathrm{Dp}$ & 42 & 43 & 42,5 & $30 \%$ & BB \\
\hline 2. & $\mathrm{Dn}$ & 44 & 46 & 45 & $31 \%$ & BB \\
\hline 3. & $\mathrm{Dt}$ & 50 & 58 & 54 & $38 \%$ & BB \\
\hline 4. & $\mathrm{Di}$ & 53 & 60 & 56,5 & $39 \%$ & BB \\
\hline 5. & $\mathrm{Fr}$ & 54 & 59 & 56,5 & $39 \%$ & BB \\
\hline 6. & $\mathrm{Ic}$ & 48 & 52 & 50 & $35 \%$ & BB \\
\hline 7. & $\mathrm{Kk}$ & 55 & 50 & 52,5 & $36 \%$ & BB \\
\hline 8. & $\mathrm{At}$ & 64 & 66 & 65 & $45 \%$ & MB \\
\hline 9. & $\mathrm{Fs}$ & 68 & 67 & 67,5 & $47 \%$ & MB \\
\hline 10. & $\mathrm{Rs}$ & 56 & 59 & 57,5 & $40 \%$ & BB \\
\hline 11 & $\mathrm{Mn}$ & 80 & 75 & 77,5 & $54 \%$ & MB \\
\hline 12 & $\mathrm{Mm}$ & 55 & 59 & 57 & $40 \%$ & BB \\
\hline 13 & $\mathrm{Wh}$ & 63 & 54 & 58,5 & $41 \%$ & BB \\
\hline 14 & $\mathrm{Ag}$ & 55 & 52 & 53,5 & $37 \%$ & BB \\
\hline 15 & $\mathrm{Rd}$ & 60 & 57 & 58,5 & $41 \%$ & BB \\
\hline & Rata-rata & $\mathbf{5 6}$ & $\mathbf{5 7}$ & $\mathbf{5 6 , 8}$ & $\mathbf{3 9 \%}$ & BB \\
\hline
\end{tabular}


Denok Dwi A, Peningkatan Kemampuan Bahasa Anak Melalui Metode Bercerita Dengan Media Diorama

Berdasarkan dari data kemampuan bahasa anak penelitian prasiklus berdasarkan table diatas, jika disajikan dalam bentuk grafik maka hasilnya sebagai berikut:



\section{Grafik Kemampuan Bahasa Anak Pada Pra-Siklus}

Berdasarkan grafik diatas, diperoleh data tentang kemampuan bahasa anak pada prasiklus yaitu dari 15 anak, sebanyak 12 anak belum berkembang dan 3 anak dengan kategori mulai berkembang dengan skor rata-rata tertinggi 77,5 atau persentase sebesar $54 \%$ diperoleh oleh $\mathrm{Mn}$ dan yang terendah dengan skor rata-rata 42,5 persentase terendah sebesar 30\% diperoleh oleh Dp. Berdasarkan hasil asesmen awal yang dilakukan oleh peneliti dan kolaborator, maka keduanya menyimpulkan bahwa untuk memberikan kegiatan menggunakan metode bercerita dengan media diorama kepada anak kelompok B yang dapat meningkatkan kemampuan bahasa anak.

Pemberian tindakan pada siklus I, maka peneliti dan kolaborator melakukan asesmen terhadap kemampuan bahasa anak. Hal ini dilakukan untuk mengetahui skor yang diperoleh anak setelah pemberian tindakan 
pada siklus I. Hasil asesmen setelah pemberian tindakan pada siklus I adalah sebagai berikut:

Tabel 2

Kemampuan Bahasa Anak Pada Siklus I

\begin{tabular}{|c|c|c|c|c|c|c|}
\hline No. & Nama Anak & Observer I & $\begin{array}{c}\text { Observer } \\
\text { II }\end{array}$ & Skor & Persentase & Ket \\
\hline 1. & $\mathrm{Dp}$ & 70 & 71 & 70,5 & $49 \%$ & MB \\
\hline 2. & $\mathrm{Dn}$ & 66 & 82 & 74 & $51 \%$ & MB \\
\hline 3. & $\mathrm{Dt}$ & 79 & 86 & 82,5 & $57 \%$ & MB \\
\hline 4. & $\mathrm{Di}$ & 86 & 87 & 86,5 & $60 \%$ & MB \\
\hline 5. & $\mathrm{Fr}$ & 87 & 90 & 88,5 & $61 \%$ & MB \\
\hline 6. & $\mathrm{Ic}$ & 87 & 84 & 85,5 & $59 \%$ & MB \\
\hline 7. & $\mathrm{Kk}$ & 79 & 75 & 77 & $53 \%$ & MB \\
\hline 8. & $\mathrm{At}$ & 95 & 90 & 92,5 & $64 \%$ & BSH \\
\hline 9. & $\mathrm{Fs}$ & 89 & 97 & 93 & $65 \%$ & BSH \\
\hline 10. & $\mathrm{Rs}$ & 90 & 85 & 87,5 & $61 \%$ & MB \\
\hline 11 & $\mathrm{Mn}$ & 93 & 100 & 96,5 & $67 \%$ & BSH \\
\hline 12 & $\mathrm{Mm}$ & 97 & 81 & 89 & $62 \%$ & MB \\
\hline 13 & $\mathrm{Wh}$ & 93 & 81 & 87 & $60 \%$ & MB \\
\hline 14 & $\mathrm{Ag}$ & 93 & 82 & 87,5 & $61 \%$ & MB \\
\hline 15 & $\mathrm{Rd}$ & 95 & 73 & 84 & $58 \%$ & MB \\
\hline & Rata-rata & $\mathbf{8 6 , 6}$ & $\mathbf{8 4 , 3}$ & $\mathbf{8 5 , 4}$ & $\mathbf{5 9 \%}$ & MB \\
\hline
\end{tabular}

Berdasarkan data kemampuan bahasa anak setelah pelaksanaan siklus I berdasarkan tabel diatas, jika disajikan dalam bentuk grafik maka hasilnya sebagai berikut:

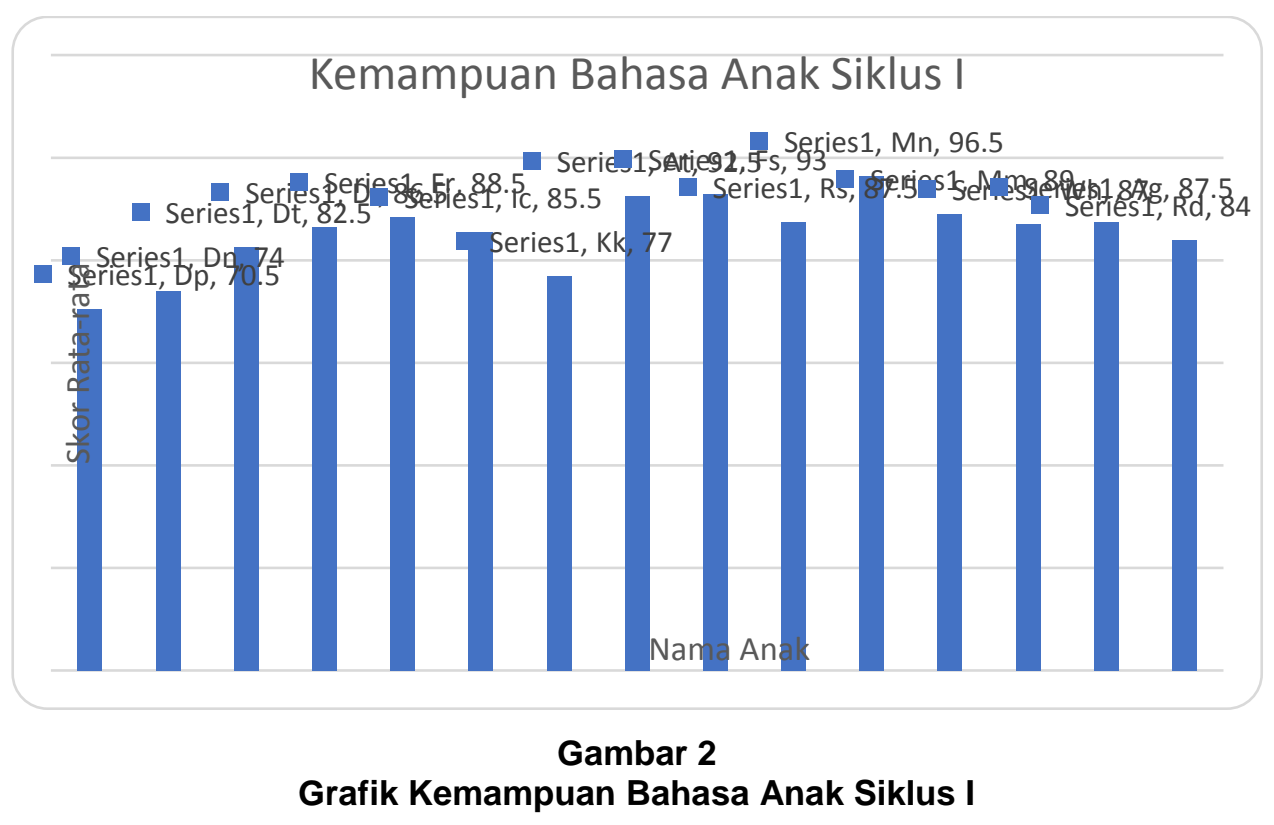


Denok Dwi A, Peningkatan Kemampuan Bahasa Anak Melalui Metode Bercerita Dengan Media Diorama

Berdasarkan hasil grafik diatas, diperoleh data tentang kemampuan bahasa anak pada siklus I, yaitu rata-rata 3 anak berada pada kategori berkembang sesuai harapan dengan skor rata-rata tertinggi sebesar 96,5 persentase $67 \%$ diperoleh oleh $\mathrm{Mn}$ dan 12 anak berada pada kategori mulai berkembang dengan skor terendah yaitu 70,5 atau $49 \%$ diperoleh oleh Dp.

Peneliti dan kolaborator telah menyepakati bahwa pemberian tindakan dikatakan berhasil jika kemampuan bahasa anak lebih menunjukkan berkembang sesuai harapan dan berkembang sangat baik. Sementara kriteria keberhasilan Tindakan yang telah diputuskan secara klasikal adalah $81 \%$. Adapun pada kriteria keberhasilan individu, ada12 anak baru mencapai kriteria mulai berkembang (MB). Sedangkan perkembangan kemampuan bahasa hanya 3 anak yang berada pada kategori berkembang sesuai harapan (BSH).

Oleh karena itu, peneliti dan kolaborator menyepakati untuk melanjutkan ke siklus II. Hal ini dilakukan atas kesepakatan antara peneliti dengan kolaborator. Hal ini juga dilakukan dengan pertimbangan agar peningkatan kemampuan bahasa anak meningkat sesuai dengan standar yang telah ditentukan dan lebih maksimal serta dapat memecahkan masalah terkait kemampuan anak dalam menyampaikan ide atau mengungkapkan kembali apa yang telah didengar. Kemampuan bahasa dari kedua belas anak tersebut dalam aspek memahami dan mengungkapkan bahasa masih perlu diberi stimulasi. Selain itu, pelaksanaan siklus II akan membuat guru lebih terbiasa dalam memberikan kegiatan untuk meningkatkan bahasa dengan menggunakan metode becerita kepada anak-anak terutama melalui media diorama.

Adapun hasil asesmen setelah pemberian tindakan pada siklus II adalah sebagai berikut: 
Tabel 3

Hasil Asesmen Siklus II Kemampuan Bahasa Anak

\begin{tabular}{|c|c|c|c|c|c|c|}
\hline No. & Nama Anak & Observer I & Observer II & Skor & Persentase & Ket \\
\hline 1. & $\mathrm{Dp}$ & 118 & 128 & 123 & $85 \%$ & BSB \\
\hline 2. & $\mathrm{Dn}$ & 104 & 132 & 118 & $82 \%$ & BSB \\
\hline 3. & $\mathrm{Dt}$ & 113 & 126 & 120 & $83 \%$ & BSB \\
\hline 4. & $\mathrm{Di}$ & 127 & 124 & 126 & $87 \%$ & BSB \\
\hline 5. & $\mathrm{Fr}$ & 129 & 131 & 130 & $90 \%$ & BSB \\
\hline 6. & $\mathrm{Ic}$ & 130 & 133 & 132 & $91 \%$ & BSB \\
\hline 7. & $\mathrm{Kk}$ & 125 & 122 & 124 & $86 \%$ & BSB \\
\hline 8. & $\mathrm{At}$ & 135 & 131 & 133 & $92 \%$ & BSB \\
\hline 9. & $\mathrm{Fs}$ & 132 & 142 & 137 & $95 \%$ & BSB \\
\hline 10. & $\mathrm{Rs}$ & 126 & 124 & 125 & $87 \%$ & BSB \\
\hline 11. & $\mathrm{Mn}$ & 93 & 100 & 141 & $98 \%$ & BSB \\
\hline 12. & $\mathrm{Mm}$ & 137 & 123 & 130 & $90 \%$ & BSB \\
\hline 13. & $\mathrm{Wh}$ & 133 & 125 & 129 & $90 \%$ & BSB \\
\hline 14. & $\mathrm{Ag}$ & 134 & 127 & 131 & $91 \%$ & BSB \\
\hline 15. & $\mathrm{Rd}$ & 135 & 121 & 128 & $89 \%$ & BSB \\
\hline \multicolumn{2}{r}{ Rata-rata } & $\mathbf{1 2 8}$ & $\mathbf{1 2 9}$ & $\mathbf{1 2 8}$ & $\mathbf{8 9}$ & BSB \\
\hline
\end{tabular}

Berdasarkan data kemampuan bahasa anak setelah siklus II pada tabel di atas, jika disajikan dalam bentuk grafik maka hasilnya sebagai berikut:

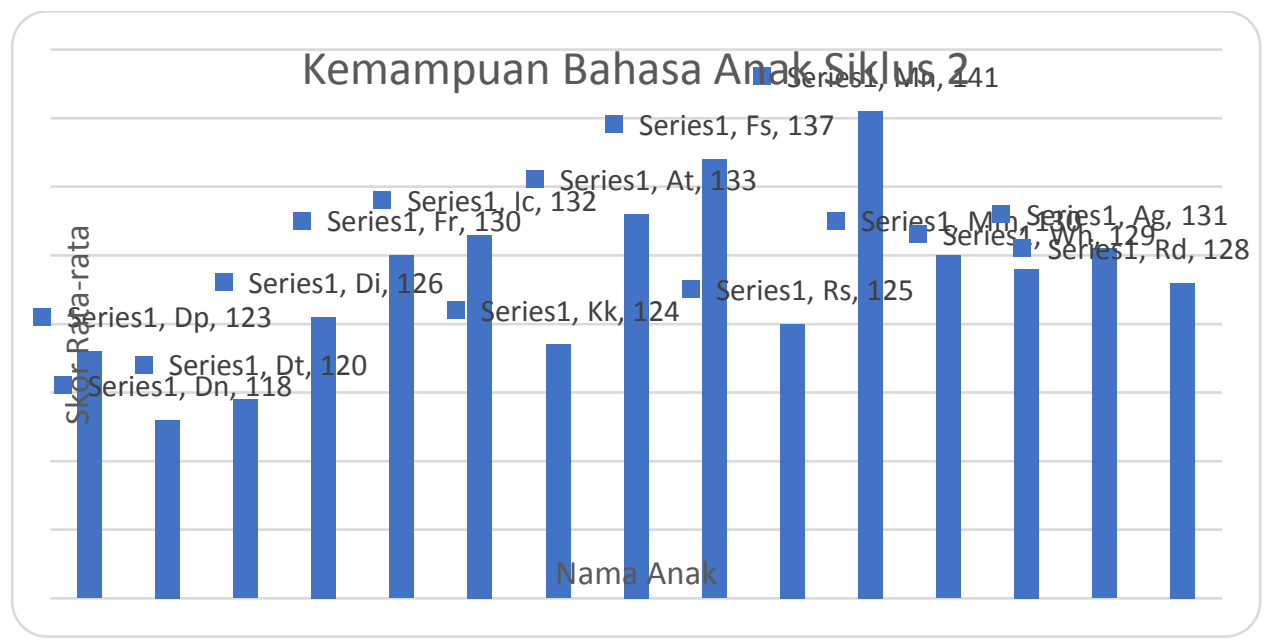

\section{Gambar 3}

Grafik Kemampuan Bahasa Anak Pada Siklus II

Berdasarkan hasil asesmen siklus II, maka nilai tertinggi dicapai oleh Mn dengan skor 141 atau 98\% dan skor terendah diperoleh Dn dengan skor 118 atau 82\%. Berdasarkan hasil persentase pencapaian anak setelah pelaksanaan siklus II, maka pemberian tindakan telah dikatakan berhasil karena target pencapaian $81 \%$ sudah tercapai. Karena 
Denok Dwi A, Peningkatan Kemampuan Bahasa Anak Melalui Metode Bercerita Dengan Media Diorama

semua anak kelompok B kemampuan bahasanya sudah mencapai berkembang sangat baik. Dari hasil pencapaian tersebut, maka peneliti dan kolaborator menyepakati bahwa pemberian tindakan hanya sampai pada siklus II.

Berdasarkan hasil penilaian penelitian prasiklus, siklus I, dan siklus Il terlihat bahwa kemampuan bahasa anak sudah mulai meningkat dari setiap pertemuannya. Hal tersebut dapat dilihat dari table peningkatan kemampuan bahasa anak mulai dari pra tindakan, siklus I sampai siklus II.

Tabel 4

Peningkatan Kemampuan Bahasa Anak

\begin{tabular}{|c|c|c|c|c|c|c|c|}
\hline \multirow{2}{*}{ No. } & \multirow{2}{*}{$\begin{array}{c}\text { Nama } \\
\end{array}$} & \multicolumn{2}{|c|}{ Pra Tindakan } & \multicolumn{2}{c|}{ Siklus I } & \multicolumn{2}{c|}{ Siklus II } \\
\cline { 3 - 8 } & Skor & Persentase & Skor & Persentase & Skor & Persentase \\
\hline 1. & $\mathrm{Dp}$ & 42,5 & $30 \%$ & 70,5 & $49 \%$ & 123 & $85 \%$ \\
\hline 2. & $\mathrm{Dn}$ & 45 & $31 \%$ & 74 & $51 \%$ & 118 & $82 \%$ \\
\hline 3. & $\mathrm{Dt}$ & 54 & $38 \%$ & 82,5 & $57 \%$ & 120 & $83 \%$ \\
\hline 4. & $\mathrm{Di}$ & 56,5 & $39 \%$ & 86,5 & $60 \%$ & 126 & $87 \%$ \\
\hline 5. & $\mathrm{Fr}$ & 56,5 & $39 \%$ & 88,5 & $61 \%$ & 130 & $90 \%$ \\
\hline 6. & $\mathrm{Ic}$ & 50 & $35 \%$ & 85,5 & $59 \%$ & 132 & $91 \%$ \\
\hline 7. & $\mathrm{Kk}$ & 52,5 & $36 \%$ & 77 & $53 \%$ & 124 & $86 \%$ \\
\hline 8. & $\mathrm{At}$ & 65 & $45 \%$ & 92,5 & $64 \%$ & 133 & $92 \%$ \\
\hline 9. & $\mathrm{Fs}$ & 67,5 & $47 \%$ & 93 & $65 \%$ & 137 & $95 \%$ \\
\hline 10. & $\mathrm{Rs}$ & 57,5 & $40 \%$ & 87,5 & $61 \%$ & 125 & $87 \%$ \\
\hline 11 & $\mathrm{Mn}$ & 77,5 & $54 \%$ & 96,5 & $67 \%$ & 141 & $98 \%$ \\
\hline 12. & $\mathrm{Mm}$ & 57 & $40 \%$ & 89 & $62 \%$ & 130 & $90 \%$ \\
\hline 13. & $\mathrm{Wh}$ & 58,5 & $41 \%$ & 87 & $60 \%$ & 129 & $90 \%$ \\
\hline 14. & $\mathrm{Ag}$ & 53,5 & $37 \%$ & 87,5 & $61 \%$ & 131 & $91 \%$ \\
\hline 15. & $\mathrm{Rd}$ & 58,5 & $41 \%$ & 84 & $58 \%$ & 128 & $89 \%$ \\
\hline & $\mathbf{R a t a}-$ & $\mathbf{5 6 , 8}$ & $\mathbf{3 9} \%$ & $\mathbf{8 5 , 4}$ & $\mathbf{5 9 \%}$ & $\mathbf{1 2 8}$ & $\mathbf{8 9 \%}$ \\
\hline & rata & & & & & & \\
\hline
\end{tabular}

Berdasarkan data peningkatan kemampuan bahasa pada table diatas, jika disajikan dalam bentuk grafik maka hasilnya sebagai berikut. 


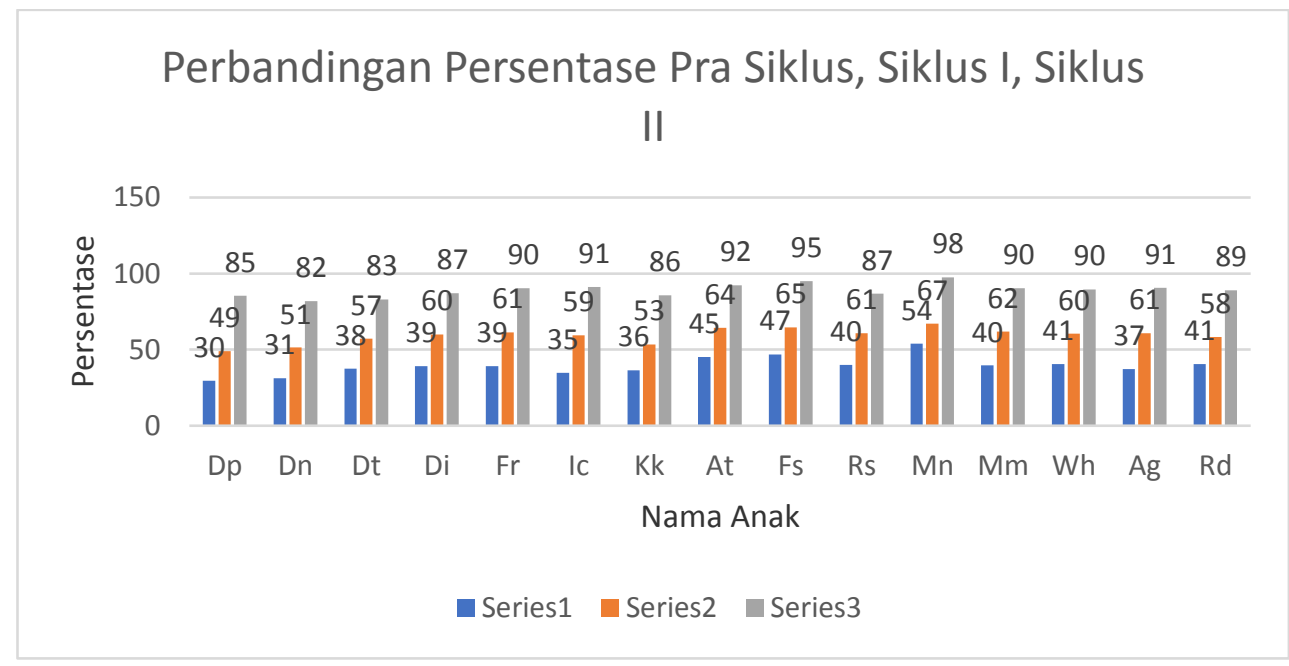

\section{Gambar 4 \\ Perbandingan Persentase Rata-rata Pra Siklus, Siklus I, dan Siklus II}

Berdasarkan data peningkatan kemampuan bahasa anak diatas, terlihat bahwa rata-rata skor kemampuan bahasa pra tindakan anak sebesar $39 \%$. Kemudian mengalami peningkatan pada siklus I sebesar $20 \%$ sehingga menjadi 59\%. Selanjutnya dari siklus I ke siklus II kemampuan bahasa anak mengalami peningkatan sebesar 30\% dari 59\% menjadi 89\%. Sehingga total peningkatan kemampuan bahasa anak mulai dari pra tindakan, siklus I sampai siklus II 39\% yaitu 59\% menjadi 89\%. Hal ini menunjukkan bahwa penelitian ini telah berhasil dan hipotesa diterima yang menyatakan bahwa kemampuan bahasa anak Kelompok B dapat meningkat melalui metode bercerita dengan media diorama. Dari hasil pencapaian tersebut, maka peneliti dan kolaborator menyepakati bahwa pemberian tindakan hanya sampai pada siklus II.

Anak-anak dapat didorong untuk memahami, membaca, dan menulis jika lingkungannya kondusif. ${ }^{17}$ Pada siklus I kegiatan pembelajaran menggunakan metode bercerita dengan media diorama ini dilakukan sebanyak 6 kali pertemuan. Pada siklus I kemampuan anak untuk mengajukan kata tanya atau mengajukan pertanyaan belum mencapai indikator kriteria keberhasilan yang telah ditetapkan. Pada

\footnotetext{
${ }^{17}$ Beaty, J.J. Skill for Preschool Teachers $5^{\text {th }}$ ed. New Jersey: Prentice Hall Inc. 1996.
} 
Denok Dwi A, Peningkatan Kemampuan Bahasa Anak Melalui Metode Bercerita Dengan Media Diorama

siklus ke II dilakukan sebanyak 6 kali pertemuan. Berdasarkan data hasil observasi siklus II terlihat bahwa dari semua anak sudah mengalami peningkatan kemampuan bahasa yang mengacu pada kriteria keberhasilan tindakan.

Akan tetapi, ada beberapa hal yang menjadi bahan refleksi peneliti dan kolaborator untuk perbaikan pemberian tindakan pada siklus II. Beberapa hal tersebut diantaranya yaitu anak-anak akan diberikan lebih banyak kesempatan untuk menjawab pertanyaan, mengungkapkan kembali isi cerita yang dibacakan oleh guru serta dapat menyebutkan simbol-simbol huruf yang ada dalam media diorama. Peran guru sebagai fasilitator, motivator, dan kolaborator dalam penelitian ini akan lebih dimaksimalkan.

Guru meminta anak untuk menaggapi isi cerita dengan menjawab pertanyaan sederhana. Pertanyaan-pertanyaan yang diajukan guru terkait isi cerita dapat dijawab dengan baik oleh anak-anak baik pada siklus I ataupun siklus II. Selanjutnya anak diminta untuk menceritakan kembali cerita yang telah disampaikan menggunakan media diorama. Anak diminta untuk menceritakan kembali isi cerita dengan urut perkenalan tokoh, waktu dan tempat. Dengan media diorama, kegiatan menggunakan metode bercerita dapat meningkatkan kemampuan bahasa anak khususnya pada aspek mengungkapkan bahasa. Pelaksanaan kegiatan pembelajaran menggunakan metode bercerita dengan media diorama ini dilakukan secara berulang-ulang. Hal ini dapat dilihat pada indicator dapat menceritakan kembali isi cerita dengan urut, perkenalan tokoh, waktu dan tempat anak dapat menceritakan kembali dengan baik dibandingkan sebelum dilakukan metode bercerita menggunakan diorama. Anak-anak lebih berantusias dalam memperkenalkan tokoh ketika menggunakan tokoh-tokoh yang terdapat dalam diorama. Ini menunjukkan bahwa diorama dapat merepresentasikan tokoh secara lebih konkrit. Hal ini didukung oleh pendapat yang menyatakan bahwa "diorama memiliki 
kelebihan yakni dapat memberikan pengalaman secara langsung dan penyajian tokoh dapat dilakukan secara lebih konkrit". ${ }^{18}$

Diorama juga merupakan hal yang baru dan memberikan pengalaman langsung pada anak sehingga anak-anak berantusias dalam bercerita. Pada indicator selanjutnya yakni dapat menceritakan karakter tokoh seperti baik, senang, nakal, pelit, baik hati, berani dan jelek anak juga dapat menceritakan karakter tokoh dengan baik menggunakan diorama, dengan adanya diorama anak-anak lebih dapat mengenali dan memahami karakter tokoh karena objek tokoh yang digunakan dalam bercerita menyerupai bentuk aslinya. Hal ini sesuai dengan pendapat Sanaky menyatakan bahwa diorama merupakan media tiga dimensi yang menggambarkan pemandangan sebenarnya. ${ }^{19}$

Media diorama yang menarik juga mendorong anak untuk mengajukan kata Tanya apa, siapa, dimana. Anak-anak merasa senang dengan diorama sehingga menumbuhkan rasa ingin tahu pada diri anak. Rasa ingin tahu pada anak membuat anak mampu mengajukan pertanyaan. Media diorama juga mendorong anak untuk memberikan tanggapan terhadap isi cerita dengan menjawab pertanyaan sederhana. Anak-anak lebih focus dalam mendengarkan cerita menggunakan media diorama sehingga dapat menjawab pertanyaan sederhana dari guru. Hal ini didukung pendapat Rahayu menyatakan bahwa penggunaan media yang menarik dapat mendorong daya. ${ }^{20}$

Metode bercerita melalui media diorama selain dapat digunakan untuk menstimulus kemampuan bahasa anak, juga dapat menstimulus percaya diri anak. Kegiatan pembelajaran menggunakan metode bercerita dengan media diorama anak menjadi lebih percaya diri dalam bercerita.

\footnotetext{
${ }^{18}$ Daryanto, op.cit.

${ }^{19} \mathrm{~A}$, Sanaky H. Media Pembelajaran Interaktif - Inovatif. Yogyakarta: Kaukaba Dipantara, 2013.

${ }^{20}$ S, Rahayu. Pengembangan Bahasa pada Anak Usia Dini. Yogyakarta: Kalimedia. 2017:15.
} 
Denok Dwi A, Peningkatan Kemampuan Bahasa Anak Melalui Metode Bercerita Dengan Media Diorama

Percaya diri anak terlihat saat anak menceritakan isi cerita anak sudah dapat bercerita dengan lafal yang jelas dan tidak ragu-ragu. Kemudian saat guru bertanya terkait dengan isi cerita yang telah disampaikan anakanak dengan antusias dan percaya diri menjawab pertanyaan dari guru dengan jawaban yang jelas, mantap dan tepat. Hal ini dapat juga meningkatkan keberanian anak untuk lebih percaya diri.

\section{KESIMPULAN}

Berdasarkan hasil temuan penelitian dan pembahasan, dapat disimpulkan bahwa: bahasa adalah segala bentuk simbol-simbol maupun rangkaian bunyi untuk menyampaikan konsep, mentransfer ide, informasi dan mampu membawakan pikiran dan perasaan yang bersifat konkrit maupun abstrak, bahasa merupakan alat komunikasi untuk menjalin pertemanan dan belajar banyak hal disekitarnya. Agar tujuan dalam pengembangan kemampuan berbahasa anak tercapai sebagai mana yang diharapkan, diperlukan strategi dan pendekatan terhadap anak.

Penelitian ini dilakukan dalam 2 siklus yaitu siklus I dan siklus II, yang setiap siklusnya ada 6 kali pertemuan. Proses peningkatan kemampuan bahasa anak pada Kelompok B dilakukan melalui metode bercerita dengan media diorama. Kegiatan pembelajaran untuk meningkatkan kemampuan bahasa anak melalui metode bercerita dengan media diorama ini merupakan media gambar tiga dimensi yang menampilkan objek yang akan dideskripsikan anak dalam bentuk yang lebih kecil. Dengan media diorama, anak mampu mengamati lebih rinci tentang suatu objek yang akan dideskripsikan, sehingga aspek memahami dan mengungkapkan bahasa dapat meningkat. Hal ini dibuktikan dengan data hasil pra siklus hingga pelaksanaan siklus I dan siklus II. Data hasil pelaksanaan tindakan menunjukkan bahwa terjadi peningkatan kemampuan bahasa anak pada tiga aspek yang ditingkatkan dalam 
penelitian ini yaitu aspek memahami bahasa, mengungkapkan bahasa dan keaksaraan.

\section{DAFTAR PUSTAKA}

Amalia, E. R. (2019). Meningkatkan Perkembangan Bahasa Anak Usia Dini Dengan Metode Bercerita. https://doi.org/10.31219/osf.io/kr5fw

Asyhar, R. (2012). Kreatif Mengembangkan Media Pembelajaran. Referensi.

Bachir, S. B. (2005). Pengembangan Kegiatan Bercerita, Teknik dan Prosedurnya. Departemen Pendidikan dan Kebudayaan.

Beaty, J. J. (1996). Skill for Preschool Teachers 5th ed. Prentice Hall Inc.

Daryanto. (2013). Media Pembelajaran. Gava Media.

Dhieni Nurbiana. (2005). Metode Pengembangan Bahasa. Universitas Terbuka.

Hemah, E., Sayekti, T., \& Atikah, C. (2018). Meningkatkan Kemampuan Bahasa Anak Melalui Metode Bercerita Pada Anak Usia 5-6 Tahun. Jurnal Penelitian Dan Pengembangan Pendidikan Anak Usia Dini, 5(1), 1. https://doi.org/10.30870/jpppaud.v5i1.4675

Kementrian Pendidikan Nasional RI. (2014). Standar Nasional Pendidikan Anak Usia Dini No 137 Tahun 2014. Peraturan Menteri Pendidikan Dan Kebudayaan Republik Indonesia, 1-76. https://portaldik.id/assets/upload/peraturan/PERMEN KEMENDIKBUD Nomor 137 Tahun 2014 STANDAR NASIONAL PENDIDIKAN ANAK USIA DINI.pdf

Kustandi, C. \& B. S. (2013). Media Pembelajaran. Ghalia Indonesia.

Musfiroh, T. (2005). Bercerita untuk Anak Usia Dini. Departemen Pendidikan Nasional.

Rahayu, S. (2017). Pengembangan Bahasa pada Anak Usia Dini. Kalimedia.

Sanaky, H. A. (2013). Media Pembelajaran Interaktif. Kaukaba Dipantara.

Semiawan, C. R. (2008). Belajar dan Pembelajaran Prasekolah dan Sekolah Dasar. PT. Indeks.

Stephen Kemmis dan Robin Mc Taggart. (1990). The Action Research Planner. Deakin University. 
Denok Dwi A, Peningkatan Kemampuan Bahasa Anak Melalui Metode Bercerita Dengan Media Diorama

Sudjana. (2005). Metode Statistika. Tarsito.

Suharsimi Arikunto. (2013). Prosedur Penelitian Suatu Pendekatan Praktik. PT. Rineka Cipta.

Suharto. (2005). Pengembangan Keterampilan Bicara Anak Usia Dini. Departemen Pendidikan Nasional.

Sumiyati. (2014). Konsep Dasar Pendidikan Anak Usia Dini dalam Islam. Indie Book Corner. 